\title{
lodine-131 labelled octreotide: not an option for somatostatin receptor therapy
}

\author{
Willem H. Bakker ${ }^{1}$, Wout A.P. Breeman ${ }^{1}$, Marcel E. van der Pluijm ${ }^{1}$, Marion de Jong ${ }^{1}$, Theo J. Visser ${ }^{2}$, \\ Eric P. Krenning ${ }^{1,2}$ \\ 1 Department of Nuclear Medicine, University Hospital Dijkzigt and Erasmus University Medical School, Rotterdam, The Netherlands \\ 2 Department of Internal Medicine III, University Hospital Dijkzigt and Erasmus University Medical School, Rotterdam, The Netherlands
}

Received 20 January and in revised form 3 March 1996

\begin{abstract}
Gamma-emitting radiopeptides are useful for scintigraphy of tumours on the basis of receptor binding. Likewise, $\beta$-emitting radiopeptides may be used in radionuclide therapy of such tumours. As iodine-131 suggested to be suitable for this purpose, experiments were performed using three somatostatin analogues, in which the effects of coupling of a therapeutic dose of ${ }^{131} \mathrm{I}$ to such peptides were investigated. This study deals with the radioiodination of very small amounts of peptide on a therapeutic scale, the required purification procedures after radioiodination, and the influence of high beta fluxes from ${ }^{131}$ I on a peptide during radioiodination and purification. Based on the regularly used therapeutic doses of ${ }^{131} \mathrm{I}$ in cancer treatment and our previous experience with [111 In-DTPA-D-Phe $\left.{ }^{1}\right]$-octreotide, it was assumed that a minimal effective therapeutic dose of $3.7 \mathrm{GBq}{ }^{131} \mathrm{I}$ has to be coupled to a maximum of $\approx 100 \mu \mathrm{g}$ peptide, representing only a slight excess of peptide over ${ }^{131} \mathrm{I}$. This contrasts with non-peptide radiopharmaceuticals in which high compound to radionuclide ratios are usually used. Labelling at low peptide to radionuclide ratios (low labelling yields) results in the formation of di-iodinated compounds, whereas at high peptide to radionuclide ratios (high labelling yields) mono-iodinated products of low specific activity are formed. Thus, after radioiodination the desired mono-iodinated peptide has to be separated from unreacted iodide, and from di-iodinated and unreacted peptide, as both compounds compete for the receptors. Possible radiolysis of the peptide during labelling and separation steps were investigated by irradiating $30 \mu \mathrm{g}$ unlabelled peptide with $370 \mathrm{MBq}{ }^{131} \mathrm{I}$ in a small volume. The peptide composition of the incubation mixtures was investigated by high-performance liquid chromatography after irradiation for $30 \mathrm{~min}$ to $24 \mathrm{~h}$. The results showed that the peptide was degraded with a half-life of less than $1 \mathrm{~h}$. During the preparation of a real therapeutic dose (at much higher $\beta$-flux) the peptide will be degraded even faster during the various
\end{abstract}

Correspondence to: W.H. Bakker, Department of Nuclear Medicine, University Hospital Dijkzigt, Dr. Molewaterplein 40, 3015 GD Rotterdam, The Netherlands steps required. In conclusion, intact mono-iodinated ${ }^{131}$ Ilabelled somatostatin analogues for peptide receptor therapy will be difficult to obtain.

Key words: Peptide - Receptor - Therapy - Tumour

Eur J Nucl Med (1996) 23:775-781

\section{Introduction}

Recently, increasing attention has been paid to scintigraphy of various processes containing receptors for peptide hormones by the application of radiolabelled analogues of these hormones. Following [123I-Tyr $\left.{ }^{3}\right]$-octreotide, [111 In-DTPA-D-Phe ${ }^{1}$-octreotide (known as Octreoscan 111 ) is nowadays extensively used for scintigraphy of somatostatin receptor-positive tumours [1-3]. Furthermore, an increasing number of publications is reporting on the use of other radioactive peptides for scintigraphic demonstration of various tumours and infectious processes [4-9]. In the case of high tumour accumulation, such peptides may also be used for radionuclide therapy, similar to ${ }^{131}$ I-iodide in the treatment of thyroid cancer and ${ }^{131} \mathrm{I}$-metaiodobenzylguanidine (MIBG) in the treatment of neuroblastoma and phaeochromocytoma.

Obviously, ${ }^{131} \mathrm{I}$ has been proposed for labelling of somatostatin analogues for radionuclide therapy of somatostatin receptor-positive tumours $[10,11]$. We assume that for radionuclide therapy with ${ }^{131}$ I-labelled peptides similar doses as are used in ${ }^{131}$ I-iodide [12] and ${ }^{131}$ I-MIBG therapy [13] will be required. Usually, only a limited amount of a bioactive peptide hormone can be administered without pharmacological side-effects, which may become a limiting factor in the coupling of a therapeutic amount of radionuclide to such a peptide. Therefore, for safety reasons it has been deemed advisable not to exceed the $100 \mu \mathrm{g}$ dose range in i.v. administration of radiolabelled somatostatin analogues. Furthermore, with $100 \mu \mathrm{g}$ i.v. octreotide, somatostatin receptors will become saturated. Based on our experience with 
Table 1. Molar ligand to radionuclide ratios for some therapeutic radiopharmaceuticals

\begin{tabular}{|c|c|c|c|}
\hline Treatment of: & $\begin{array}{l}\text { Radionuclide } \\
\text { (radioactivity } \\
\text { and mass) }\end{array}$ & $\begin{array}{l}\text { Compound } \\
\text { (mass) }\end{array}$ & $\begin{array}{l}\text { Excess of } \\
\text { compound } \\
\text { over } \\
\text { radionuclide }\end{array}$ \\
\hline Pain & $\begin{array}{l}186 \mathrm{Re} \\
1295 \mathrm{MBq} \\
4.7 \times 10^{-8} \mathrm{~mol}\end{array}$ & $\begin{array}{l}\text { HEDP } \\
5 \mathrm{mg} \\
2 \times 10^{-5} \mathrm{~mol}\end{array}$ & 430 \\
\hline $\begin{array}{l}\text { Neuroblas- } \\
\text { toma }\end{array}$ & $\begin{array}{l}131 \mathrm{I} \\
3700 \mathrm{MBq} \\
3.8 \times 10^{-8} \mathrm{~mol}\end{array}$ & $\begin{array}{l}\text { MIBG } \\
3.3 \mathrm{mg} \\
8 \times 10^{-6} \mathrm{~mol}\end{array}$ & 210 \\
\hline $\begin{array}{l}\text { Various } \\
\text { malignancies }\end{array}$ & $\begin{array}{l}90 \mathrm{Y} \\
3700 \mathrm{MBq} \\
2.1 \times 10^{-9} \mathrm{~mol}\end{array}$ & $\begin{array}{l}\text { MoAb } \\
20 \mathrm{mg} \\
1.3 \times 10^{-7} \mathrm{~mol} \\
\text { MoAb fragment } \\
20 \mathrm{mg} \\
4.0 \times 10^{-7} \mathrm{~mol} \\
\mathrm{MoAb} \\
20 \mathrm{mg} \\
1.3 \times 10^{-7} \mathrm{~mol} \\
\text { MoAb } \\
\text { fragment } \\
20 \mathrm{mg} \\
4.0 \times 10^{-7} \mathrm{~mol}\end{array}$ & 190 \\
\hline $\begin{array}{l}\text { Endocrine } \\
\text { tumours }\end{array}$ & $\begin{array}{l}111 \mathrm{In} \\
3700 \mathrm{MBq} \\
2.2 \times 10^{-9} \mathrm{~mol} \\
13 \mathrm{I} \\
3700 \mathrm{MBq} \\
3.8 \times 10^{-8} \mathrm{~mol}\end{array}$ & $\begin{array}{l}\text { DTPA-octreotide } \\
100 \mu \mathrm{g} \\
6.7 \times 10^{-8} \mathrm{~mol} \\
\text { Peptide } \\
100 \mu \mathrm{g} \\
6.7 \times 10^{-8} \mathrm{~mol}\end{array}$ & 1.75 \\
\hline
\end{tabular}

[111In-DTPA-D-Phe1]-octreotide [14, 15], it was estimated that an effective therapeutic dose of $\approx 3.7 \mathrm{GBq}$ (38 nmol) ${ }^{131} \mathrm{I}$ has to be coupled to $\approx 100 \mu \mathrm{g}(67 \mathrm{nmol})$ of a somatostatin analogue $(M \approx 1.5 \mathrm{kDa})$, i.e. nearly a twofold excess of peptide over radionuclide. This is in sharp contrast to the high molar compound to radionuclide ratios of most radiopharmaceuticals. Table 1 shows these ratios for some radiotherapeutic agents. However, as described previously [16], radioiodination of [ $\left.\mathrm{Tyr}^{3}\right]$-octreotide using only a small excess of peptide over radionuclide results in a considerable amount of di-iodinated $\left[\mathrm{Tyr}^{3}\right]$-octreotide, which no longer binds to the somatostatin receptor [17]. Therefore, we investigated the results of radiolabelling of two somatostatin analogues, [Tyr ${ }^{3}$ ]-octreotide and [DTPA-D-Phe $\left.{ }^{1}\right]-R C-160$ (Fig. 1), at different molar peptide to nuclide ratios, simulating conditions during the preparation of a therapeutic dose. ${ }^{125}$ I was used as a model for ${ }^{131}$ I because of its wellcharacterized specific radioactivity.

During the necessary high-performance liquid chromatography (HPLC) and/or SEP-PAK purification steps after labelling on a therapeutic scale with ${ }^{131} \mathrm{I}$, high beta fluxes originate due to the concentration of the radiola-

\section{DTPA-D-Phe-Cys-Phe-D-Trp-Lys-Thr-Cys-Thr(ol)}

Fig. 1. Structural formulae of $\left[\mathrm{Tyr}^{3}\right]$-octreotide (A), [DTPA-DPhe']-RC-160 (B) and [DTPA-D-Phe']-octreotide (C)

belled peptides in narrow zones of column material. Therefore, radiolytic effects under therapeutic circumstances were simulated by exposing unlabelled peptide in a small volume to a high dose of ${ }^{131}$ I-beta radiation over various time intervals. Afterwards, the radiation damage was investigated by HPLC.

\section{Materials and methods}

Peptides. [Tyr ${ }^{3}$ ]-octreotide and [DTPA-D-Phe ${ }^{1}$-octreotide were obtained from Sandoz (Basle, Switzerland) and [DTPA-D-Phel]RC-160 from Sanbio (Uden, The Netherlands).

Quality control of unlabelled peptides. The original peptides were analysed by reversed-phase HPLC with a Waters $600 \mathrm{E}$ multisolvent delivery system connected to a $\mu$-Bondapak- $\mathrm{C}_{18}$ reversedphase column $(300 \times 3.9 \mathrm{~mm}$, particle size $10 \mu \mathrm{m})$ with UV detection $(254 \mathrm{~nm})$. Elution was carried out at a flow rate of $1 \mathrm{ml} / \mathrm{min}$ with a linear gradient of $40 \%-80 \%(\mathrm{v} / \mathrm{v})$ methanol in $50 \mathrm{~m} M \mathrm{Na}$ acetate buffer ( $\mathrm{pH} 5.5$ ) for $20 \mathrm{~min}$ and the composition was maintained for another $5 \mathrm{~min}$.

Radioiodination of peptides and quality control of radioiodinated peptides. [Tyr ${ }^{3}$-octreotide and [DTPA-D-Phe ${ }^{1}$ ]-RC-160 were radioiodinated with ${ }^{125} \mathrm{I}$ as described previously [16]. [Tyr $\left.{ }^{3}\right]$-octreotide $(4.3-105 \mu \mathrm{g})$ was labelled with ${ }^{125} \mathrm{I}(92.5-370 \mathrm{MBq})$, corresponding to molar peptide to radionuclide ratios of $1.7-43$. [DTPA-D-Phe ${ }^{1}$ ]-RC-160 $(1.3-125 \mu \mathrm{g})$ was labelled with ${ }^{125}$ I (37-370 MBq), corresponding to molar peptide to radionuclide ratios of $1.7-31$.

After radiolabelling, the peptide components in the reaction mixture were isolated on a SEK-PAK $\mathrm{C}_{18}$ reversed-phase extraction cartridge as described previously [16], and analysed with the HLPC system described above. Eluted radioactivity was monitored on-line using an NaI probe connected to a Canberra singlechannel analyser with a recorder. Collected fractions were measured by routine scintillation counting. Isolated peaks were concentrated and reinjected into the HPLC system in order to confirm the integrity of the radiolabelled peptide.

Investigation of radiolysis of peptides during purification steps. The effects of high beta fluxes emanating from a therapeutic dose of ${ }^{131} \mathrm{I}$ on microgram amounts of unlabelled peptide were investigated, simulating geometrical conditions during the mandatory purification steps. For this purpose [DTPA-D-Phe ${ }^{l}$-octreotide was used, as only of this octreotide analogue was sufficient pure compound available. In nine different irradiation experiments a well- 
defined amount of ${ }^{131} \mathrm{I}(370 \mathrm{MBq}$ in $167 \mu$ l $0.05 \mathrm{M}$ phosphate) was incubated for $0.5-24 \mathrm{~h}$ at room temperature with [DTPA-DPhe $^{1}$-octreotide ( $30 \mu \mathrm{g}$ in $150 \mu \mathrm{l} 0.05 \mathrm{M}$ acetic acid) in a small polyethylene cup. The radiation absorbed dose in the reaction volume amounted to $130 \mathrm{~Gy} / \mathrm{h}$. Radiolysis under these circumstances was investigated by HPLC with UV detection of the unlabelled peptide and its degradation products at $254 \mathrm{~nm}$. In a control experiment in the absence of ${ }^{131} \mathrm{I}$, the stability of the peptide was tested at room temperature without irradiation.

\section{Results}

\section{Peptide composition before and after radioiodination}

The HPLC elution pattern (monitored at $254 \mathrm{~nm}$ ) of $\left[\mathrm{Tyr}^{3}\right]$-octreotide showed one peak (data not shown), while those of [DTPA-D-Phe']-RC-160 and [DTPA-D$\mathrm{Phe}^{1}$ ]-octreotide consisted of three peaks (data not shown), corresponding to the data reported by the manufacturers.

Peptide radiolabelling yields amounted to $31 \%-93 \%$ as measured by SEP-PAK elution. Typical examples of the radioactive peptide composition in the reaction mixtures with different molar peptide to radioiodide ratios are shown in Fig. 2 ([Tyr $\left.{ }^{3}\right]$-octreotide) and Fig. 3 ([DTPA-D-Phe $\left.\left.{ }^{1}\right]-R C-160\right)$. At molar peptide to ${ }^{125}$ I ratios of $41,3.5$ and 1.7 , radioiodination of [Tyr $\left.{ }^{3}\right]$-octreotide yielded $96 \% / 4 \%, 75 \% / 25 \%$ and $60 \% / 40 \%$ mono-/di-iodinated peptide, respectively. In the case of labelling of [DTPA-D-Phe ${ }^{1}$ ]-RC-160 at molar peptide to ${ }^{125}$ I ratios of 17 and $1.7,82 \%$ and $56 \%$ of the labelled peptides were mono-iodinated, respectively. Thus, at higher molar peptide to radionuclide ratios far more mono-iodinated than di-iodinated peptides are formed. In the case of [DTPAD-Phe ${ }^{1}$-RC-160, the HPLC elution profile of the monoiodinated compound shows three peaks, like that of the original unlabelled compound. After reinjection of each of these three peaks into the HPLC the same three original peaks were again observed, indicating that this peptide exists in three interconvertable forms (data not shown).

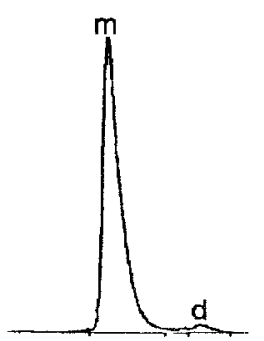

A

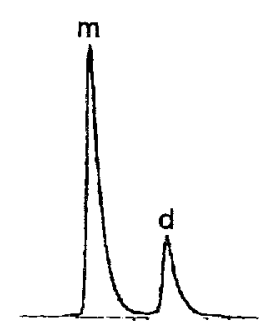

B

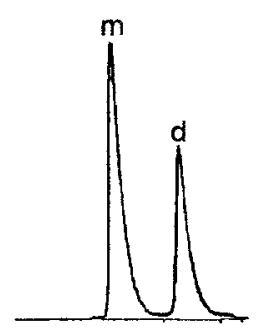

C
Fig. 2. Typical HPLC elution patterns of the reaction mixtures after radioiodination of $\left[\mathrm{Tyr}^{3}\right]$-octreotide at three different molar peptide to radionuclide ratios $-43(\mathbf{A}), 3.5(\mathbf{B})$ and $1.7(\mathbf{C})$ - measured by on-line gamma counting. $m$, Mono-iodinated peptide; $d$, di-iodinated peptide

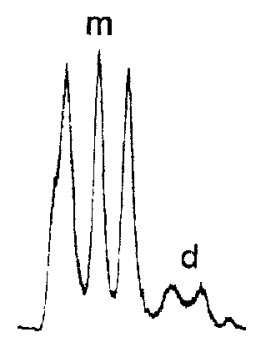

A

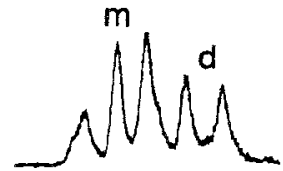

B
Fig. 3. Typical HPLC elution patterns of the reaction mixtures after radioiodination of [DTPA-D-Phe ${ }^{1}$ ]-RC-160 at two different molar peptide to radionuclide ratios -17 (A) and 1.7 (B) - measured by on-line gamma counting. $m$, Mono-iodinated peptide; $d$, di-iodinated peptide

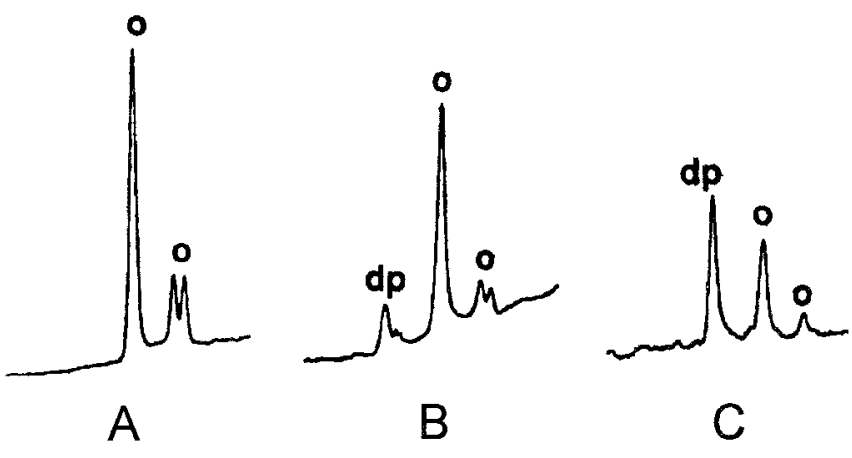

Fig. 4. Typical HPLC elution patterns before (A) and $30 \mathrm{~min}$ (B) and $4 \mathrm{~h}(\mathbf{C})$ after irradiation of $30 \mu \mathrm{g}$ [[DTPA-D-Phe ${ }^{1}$-octreotide by $370 \mathrm{MBq}{ }^{131}$ I iodide, measured by UV absorption at $254 \mathrm{~nm}$. $o$, Original peptide; $d p$, degradation products

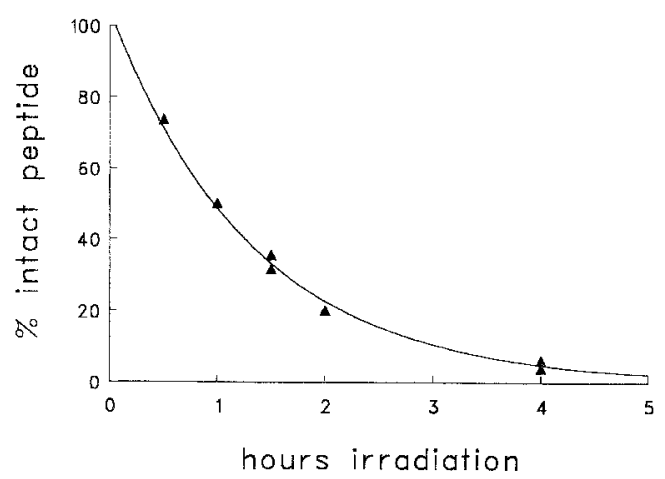

Fig. 5. Remaining [DTPA-D-Phe' ${ }^{1}$-octreotide after irradiation by ${ }^{131}$ I as a function of time expressed as a percentage of the original amount, measured by UV absorption at $254 \mathrm{~nm}$

\section{Radiolysis by high beta-fluxes}

In Fig. 4 the degradation of [DTPA-D-Phe ${ }^{1}$-octreotide by the beta radiation of ${ }^{131} \mathrm{I}$ is shown under circumstances approaching those occurring during separation steps. The figure shows the HPLC elution profiles of the original (unlabelled) compound and the irradiation mixture after $30 \mathrm{~min}$ and $4 \mathrm{~h}$ of irradiation. After irradiation new peaks with shorter retention times are formed while the peak of the original peptide declines. After $24 \mathrm{~h}$ no orig- 
inal peptide nor any degradation product was detected in the HPLC eluate (data not shown). The irradiation experiment shows that the original peptide is destroyed under these conditions with a half-life of less than $1 \mathrm{~h}$ (Fig. 5). In a control experiment the peptide remained intact for $24 \mathrm{~h}$ at room temperature in the absence of ${ }^{131} \mathrm{I}$ (data not shown).

\section{Discussion}

With the growing number of publications on somatostatin receptor scintigraphy, the question arises as to whether peptides also may be used in radionuclide therapy of somatostatin receptor-positive lesions. Usually, radiopharmaceuticals are prepared using a high compound to radionuclide ratio, resulting in labels with low specific activity. Because in most instances radionuclide therapy is based on mechanisms with high accumulation capacity, this is usually no drawbacks. Thus, radionuclide therapy is usually not limited by the mass of the administered radiopharmaceutical. However, in radionuclide receptor therapy a much higher specific activity is required. As in this case compounds are accumulated by specific, saturable receptor binding, efficient radionuclide receptor therapy requires an optimal mass of peptide with sufficient activity of a suitable radionuclide. Depending on the physical characteristics of the radionuclide and the metabolic properties of the radiolabelled compound, radionuclide receptor therapy requires a similar amount of radiation as is used in radioiodide therapy of thyroid cancer, i.e. equivalent to a minimal dose of $3700 \mathrm{MBq}{ }^{131} \mathrm{I}$. Such a dose has to be coupled with a small amount of peptide.

\section{Optimal mass of peptide}

In order to deliver the highest possible radiation dose to a tumour, an optimal mass of peptide labelled with high activity is required. This mass is dependent on various, often unknown, parameters, such as saturation (administered mass and endogenous peptide) and up- or downregulation of receptors at higher peptide doses. Ligandspecific accumulation of [ ${ }^{111}$ In-DTPA-D-Phel ${ }^{1}$-octreotide in somatostatin receptor-positive tissues was initially increased by injecting more peptide [18]. Similar observations showed enhanced visualization of tumours in patients during octreotide treatment [19-22]. Scintigraphy after administration of [ ${ }^{111}$ In-DTPA-D-Phe $\left.{ }^{1}\right]$-octreotide with different amounts of unlabelled [DTPA-DPhe $^{1}$ ]-octreotide suggested an optimal range of 5-120 $\mu \mathrm{g}$ (3.3-80 nmol) peptide [14]. When [111 In-DTPA-D-Phe']octreotide was used therapeutically for the first time, it was in this same dose range [15]. However, routine octreotide treatment is performed with daily subcutaneous doses of several hundred micrograms of octreotide, probably causing upregulation of receptors [19-22]; consequently octreotide in blood will not attain the level reached after i.v. administration of $100 \mu \mathrm{g}$, as is used in radionuclide therapy. Intravenous administration of higher doses of (unlabelled) peptide will therefore only saturate receptors without the desired radiotherapeutic effect. Furthermore, not only receptor occupation but also unwanted pharmacological side-effects may limit the administration of bioactive peptides. Therefore, the highest radionuclide tumour uptake ( $\%$ dose) is assumed to be achieved with $100 \mu \mathrm{g}(67 \mathrm{nmol})$ of $1.5-\mathrm{kDa}$ somatostatin analogue. Independent of the used radionuclide, an equivalent mass of radiolabelled somatostatin analogue will thus be required for radionuclide therapy, assuming that its metabolic properties are comparable to those of [111 In-DTPA-D-Phe ${ }^{1}$ ]-octreotide.

\section{Choise of a suitable radionuclide}

Recently, in addition to radionuclides emitting mediumand high-energy beta particles, attention has been paid to radionuclides that are commonly used for gamma camera scintigraphy. It is suggested that these radionuclides may also find therapeutic use on the basis of their low energetic conversion and Auger electrons. The radiation energy of these electrons is deposited within the direct vicinity of the disintegrating radionuclide. This category includes gallium-67 and indium-111 [23-26]. The question arises as to whether such a radionuclide, coupled to a peptide, is sufficiently internalized by the cell that the emitted low-energy particles will reach the nucleus. That this may be the case was suggested by the successful treatment of a glucagonoma patient with [111In-DTPA-D$\left.\mathrm{Phe}^{1}\right]$-octreotide [15]. In this study we paid attention to the possibility of preparing and purifying radioiodinated peptides for peptide receptor therapy because ${ }^{131}{ }^{1}$-iodide is most frequently used in therapeutic nuclear medicine (for the treatment of hyperthyroidism, goitre and thyroid cancer). In the form of ${ }^{131}$ I-MIBG, ${ }^{131} \mathrm{I}$ is successfully used in treatment of neuroblastoma and phaeochromocytoma.

\section{Labelling of peptides with ${ }^{131}$ I}

The proposed $3.7 \mathrm{GBq}{ }^{131} \mathrm{I}$ ( $38 \mathrm{nmol}$, see Table 2 ) iodide must be bound to the presumed optimal mass (100 $\mu g=67 \mathrm{nmol}$ peptide). Incorporation of more than one iodine atom into the tyrosine of $\left[\mathrm{Tyr}^{3}\right]$-octreotide results in the loss of receptor binding [17]. Although the use of ${ }^{131} \mathrm{I}$ is more appropriate to test the different labelling conditions, this radionuclide is not available in the welldefined specific activity required for the molar-ratio experiments. Therefore, ${ }^{125} \mathrm{I}$ was used as a model because of its known specific activity $\left(8 \times 10^{16} \mathrm{~Bq} / \mathrm{mol}\right)$.

Our peptide experiments with ${ }^{125} \mathrm{I}$ demonstrate that low excesses of peptide over radionuclide result in relatively large fractions of di-iodinated compounds, while a 
Table 2. Theoretical (=lowest) and practical masses of $3.7 \mathrm{GBq}$ radionuclide

\begin{tabular}{|c|c|c|}
\hline $\begin{array}{l}\text { Radio- } \\
\text { nuclide }\end{array}$ & $\begin{array}{l}\text { Theory } \\
\text { (nmol) }\end{array}$ & $\begin{array}{l}\text { Practice } \\
\text { (nmol) }\end{array}$ \\
\hline${ }^{13 !} I$ & 6.17 & 38.2 \\
\hline${ }^{90} \mathrm{Y}$ & 2.07 & 2.07 \\
\hline${ }^{186} \mathrm{Re}$ & 2.91 & 133 \\
\hline${ }^{32} \mathrm{P}$ & 11 & 11 \\
\hline $114 m I n$ & 38.3 & $?$ \\
\hline${ }^{161} \mathrm{~Tb}$ & 5.29 & $?$ \\
\hline${ }^{67} \mathrm{Ga}$ & 2.53 & 2.53 \\
\hline $111 \mathrm{In}$ & 2.17 & 2.17 \\
\hline $125 \mathrm{I}$ & 46.0 & 46.0 \\
\hline
\end{tabular}

large excess of peptide over radionuclide mainly causes the formation of the mono-iodinated compounds (Figs. 2,3), with, of course, much peptide remaining unlabelled. Preparative HPLC separations will therefore be required to separate the wanted radiopeptide from unlabelled peptide, di-iodinated peptide and unreacted radioiodide. The radiopeptide is concentrated in very small volumes during necessary purification on HPLC and/or SEP-PAK columns and, hence, is subject to radiolytic damage (Fig. 5). Radiolytic damage can be prevented using a suitable radiation quencher such as gentisic acid [27], but its radiation quenching effect cannot be guaranteed during the SEP-PAK and HPLC purification steps. Therefore, ${ }^{131}$ I seems unsuitable for radionuclide somatostatin receptor therapy. An additional drawback of the use of radioiodine for peptide receptor therapy is that ${ }^{131}$ I will be released from tumours in the same way as such release occurs after the administration of antibody fragment-bound radioiodine [28]. Conversely, radiometals that are chelated to antibody fragments tend to be retained by tumours [28]. Therefore, in the following, a one-step alternative approach will be discussed in which, instead of ${ }^{131} \mathrm{I}$, residualising radiometals, such as yttrium, are used in the presence of a radiation quencher.

\section{Direct radiolabelling of chelator-conjugated peptides with radiometals}

A well-known method in the daily practice of nuclear medicine is the simple one-step preparation of radiopharmaceuticals that does not require additional purification steps. Such direct radiolabelling can be performed in the presence of a suitable radiation quencher and will therefore be preferred for preparing radiopeptides for therapy. Peptides and proteins conjugated with polyaminopolycarboxylic acids such as EDTA, DTPA and DOTA are suitable for such a one-step labelling procedure with radiometals. ${ }^{11} \mathrm{In}$ and ${ }^{90} \mathrm{Y}$ are frequently used to label proteins conjugated with DTPA groups for diagnostic and therapeutic purpose respectively. Although the binding between ${ }^{90} \mathrm{Y}$ and DTPA appeared to be stable in vitro, this radionuclide is released from the DTPA group in vivo, resulting in unfavourable bone accumula- tion [29]. This is especially the case when one acetic acid group of DTPA is linked to the protein and, hence, is not available for ${ }^{90} \mathrm{Y}$ complexation [29]. In carbon backbone-linked DTPA groups, such as SCN-Bz-DTPA, ${ }^{90} \mathrm{Y}$ is far more tightly bound under physiological conditions, probably because all five carboxyl groups participate in ${ }^{90} \mathrm{Y}$ complexation. In addition, peptides may also be derivatized with polyazamacrocycles, such as the DOTA group, that bind ${ }^{90} \mathrm{Y}$ with very high affinity [30]. Recently, preliminary animal experiments with an octadentate octreotide derivative labelled with ${ }^{90} \mathrm{Y}$ showed promising results with respect to in vivo stability as well as inhibition of tumour growth [31].

Furthermore, somatostatin analogues have been coupled successfully with rhenium-188 using a ${ }^{188} \mathrm{~W} /{ }^{188} \mathrm{Re}$ generator and routine kit coupling, although metabolic properties (hepatobiliary clearance and low tumour to normal tissue ratios) will limit their use in humans [32, 33]. Other therapeutic radiometals suitable for one-step radionuclide coupling, such as terbium-161 (included in the DTPA group), are not yet generally available.

In the absence of a convenient and suitable method for obtaining ${ }^{131}$ I-labelled peptides, the one-step labelling procedure using chelator-conjugated peptides to bind beta-decaying radiometals, such as ${ }^{90} \mathrm{Y}, 114 \mathrm{~m}$ In (decaying to the $\beta$-emitting ${ }^{114} \mathrm{In}$ ) and ${ }^{161} \mathrm{~Tb}$, will be the current method of choise, although the availability of ultrapure radionuclides is still limited. Such radiolabelling will have to meet the same specific activity requirements as are described above (i.e. the highest possible activity of a radionuclide coupled to the optimal mass of peptide), which seems possible for many short-lived radionuclides in the absence of their isotopes and other metallic contaminants. In Table 2 the theoretical numbers of mols corresponding to $3.7 \mathrm{GBq}$ of some radionuclides are compared with the attainable values in practice. This illustrates that certainly not all short-lived radionuclides will reach the high therapeutic specific activity required for coupling a high therapeutic radionuclide dose to a relatively small amount of peptide. ${ }^{90} \mathrm{Y}$ is a good candidate in this respect, but few if any peptides are available conjugated with a suitable chelator such as the DOTA group. Our preliminary experience shows that ${ }^{161} \mathrm{~Tb}$ binds well to [DTPA-D-Phe ${ }^{1}$-octreotide [34] and may be suitable for radionuclide receptor therapy. Finally, the problem of high physiological accumulation of chelatorconjugated radiopharmaceuticals in vital organs, such as the kidneys, deserves further investigation.

\section{Conclusion}

Intact mono-iodinated 131 I-labelled somatostatin analogues are hard to obtain in radiotherapeutic amounts, since further separations are necessary during which radiation damage to the peptide will occur due to enrichment of the radionuclide in small volumes. For peptide receptor radionuclide therapy direct labelling of a radio- 
metal such as ${ }^{90} \mathrm{Y}$ or ${ }^{161} \mathrm{~Tb}$ to a chelator-conjugated peptide in the presence of a suitable radiation quencher appears far more easily attainable. A second advantage may be that radiometals will probably be better retained in tumours than radioiodine. However, many problems regarding radionuclide purity and synthesis of suitable chelator-conjugated peptides remain to be solved.

\section{References}

1. Bakker WH, Krenning EP, Breeman WA, Kooij PPM, Reubi JC, Koper JW, de Jong M, Lameris JS, Visser TJ, Lamberts SWJ. In vivo use of a radioiodinated somatostatin analogue: dynamics, metabolism, and binding to somatostatin receptorpositive tumours in man. $J$ Nucl Med 1991 ; 32: 1184-1189.

2. Krenning EP, Bakker WH, Kooy PPM, Breeman WAP, Oei HY, Reubi JC, Visser TJ, Bruns C, Kwekkeboom DJ, Reijs AEM, van Hagen PM, Koper JW, Lamberts SWJ. Somatostatin receptor scintigraphy with [11!In-DTPA-D-Phel]-octreotide in man: metabolism, dosimetry and comparison with ${ }^{123} I-$ $\mathrm{Tyr}^{3}$ ]-octreotide. $J$ Nucl Med 1992; 33: 652-658.

3. Krenning EP, Kwekkeboom DJ, Bakker WH, Breeman WAP, Kooij PPM, Oei HY, Van Hagen M, de Jong M, Reubi JC, Visser TJ, Reijs AEM, Hofland LJ, Koper JW, Lamberts SWJ. Somatostatin receptor scintigraphy with [111 In-DTPA-D-Phe $\left.{ }^{1}\right]$ and [123 $\left.{ }^{1}-\mathrm{Tyr}^{3}\right]$-octreotide: the Rotterdam experience with more than 1000 patients. Eur J Nucl Med 1993; 20: 716731.

4. Fischman AJ, Babich JW, Strauss HW. A ticket to ride: peptide radiopharmaceuticals. I Nucl Med 1993; 34: 2253-2263.

5. Virgolini I, Raderer M, Angelberger P, Banyai S, Scheithauer W, Valent P. Vasoactive intestinal peptide (VIP) receptor imaging in the localization of intestinal adenocarcinomas and endocrine tumors. $J$ Nucl Med 1994; 5: 97P.

6. Virgolini I, Raderer M, Kurtaran A, Angelberger P, Banyai S, Yang Q, Li S, Banyai M, Niederle B, Scheithauer W, Valent P. Vasoactive intestinal peptide-receptor imaging for the localization of intestinal adenocarcinomas and endocrine tumors. $N$ Engl J Med 1994; 331: 1116-1121.

7. Babich JW, Graham W, Barrow SA, Dragotakes SC, Tompkins DG, Rubin RH, Fischman AJ. Technetium-99m-labelled chemotactic peptides: comparison with indium-111-labelled white blood cells for localizing acute bacterial infection in the rabbit. I Nucl Med 1993; 34: 2176-2181.

8. Wolf H, Marschall F, Scheffold N, Clause M, Schramm M, Henze E. Iodine-123 labelling of atrial natriuretic peptide and its analogues: initial results. Eur J Nucl Med 1993; 20: 297301.

9. Solomon HF, Derlan CK, Beblavy, Jester D, Santull R, Pike M, Kroon D, Hoey K, Fischman AJ. Focal infection imaging using an In-111 labelled antagonist chemotactic peptide. $J$ Nucl Med 1994; 35: 45P.

10. Breeman WAP, Hofland LJ, Bakker WH, van der Pluijm ME, Koetsveld PM, de Jong M, Setyono-Han B, Kwekkeboom DJ, Visser TJ, Lamberts SWJ, Krenning EP. Radioiodinated somatostatin analogue RC-160: preparation, biological activity, in vivo application in rats and comparison with [ $\left.{ }^{123} \mathrm{I}_{-} \mathrm{Tyr}^{3}\right]$-octreotide. Eur J Nucl Med 1993; 20: 1089-1094.

11. Buxton-Thomas M, Ramage JK, Williams R. Comparison of indium-111-labelled octreotide and I-123-metaiodobenzylguanidine imaging in patient with secondary carcinoid tumours of the liver. Eur J Nucl Med 1994; 21(Suppl): 200.
12. Freitas JE, Gross MD, Ripley S, Shapiro B. Radionuclide diagnosis and therapy of thyroid cancer: current status report. Semin Nucl Med 1985; 15: 106-131.

13. Hoefnagel CA, Radionuclide therapy revisited. Eur $J \mathrm{Nucl}$ Med 1991; 18: 408-431.

14. Kooij PPM, Kwekkeboom DJ, Breeman WAP, Reijs AEM, Bakker WH, Lamberts SWJ, Visser TJ, Krenning EP. The effects of specific activity on tissue distribution of $\left[{ }^{111}\right.$ In-DTPAD-Phe ${ }^{1}$ ]-octreotide in humans. J Nucl Med 1994; 35: 226P.

15. Krenning EP, Kooij PPM, Bakker WH, Breeman WAP, Postema PTE, Kwekkeboom DJ, Oei HY, de Jong M, Visser TJ, Reijs AEM, Lamberts SWJ. Radiotherapy with a radiolabelled somatostatin analogue, [ ${ }^{111}$ In-DTPA-D-Phe ${ }^{1}$-octreotide. A case history. Ann N Y Acad Sci 1994; 733: 496-506.

16. Bakker WH, Krenning EP, Breeman WA, Koper JW, Kooij PPM, Reubi JC, Klijn JG, Visser TJ, Doctor R, Lamberts SWJ. Receptor scintigraphy with a radioiodinated somatostatin analogue: radiolabelling, purification, biologic activity, and in vivo application in animals. $J$ Nucl Med 1990; 31: 1501-1509.

17. Reubi JC. New specific radioligand for one subpopulation of brain somatostatin receptors. Life Sci 1985; 36: 1829-1836.

18. Breeman WAP, Kwekkeboom DJ, Kooij PPM, Bakker WH, Hofland LJ, Visser TJ, Ensing GJ, Lamberts SWJ, Krenning EP. Effect of dose and specific activity on tissue distribution of ${ }^{111}$ In-pentetreotide in rats. J Nucl Med 1995; 36: 623-627.

19. Dörr U, Räth U, Sautter-Bihl M-L, Guzman G, Bach D, Adrian H-J, Bihl H. Improved visualization of carcinoid liver metastases by indium-111 pentetreotide scintigraphy following treatment with cold somatostatin analogue. Eur $J$ Nucl Med 1993; 20: 431-433.

20. Dörr U, Wurm K, Horing E, Guzman G, Räth U, Bihl H. Diagnostic reliability of somatostatin receptor scintigraphy during continuous treatment with different somatostatin analogues. Horm Metab Res 1993; 27(Suppl): 36-43.

21. Becker W, Behr Th, Pavel M, Hensen J, Wolff F. In-111-Octreotid-Scintigraphie unter Somatostatintherapie. Nukl Med 1994; 33: 4986.

22. Soresi E, Bombardieri E, Chiti A, Boffi R, Invernizzi G, Crippa F, Maffioli L. Indium-111-DTPA-octreotide scintigraphy modulation by treatment with unlabelled somatostatin analogue in small-cell lung cancer. Tumori 1995; 81: 125-127.

23. Murty Goddu S, Howell RW, Rao DV. Cellular dosimetry: absorbed fractions for monoenergetic electron and alpha particle sources and $\mathrm{S}$-values for radionuclides uniformly distributed in different cell compartments. J Nucl Med 1994; 35: 303-316.

24. Jonkhoff AR, Huijgens PC, Versteegh RT, van Dieren EB, Ossenkoppele GJ, Martens HJM, Teule GJJ. Gallium-67 radiotoxicity in human U937 lymphoma cells. Br J Cancer 1993; 67: 693-700.

25. Jonkhoff AR, van Dieren EB, Huijgens PC, Versteegh RT, Dräger A, van der Loosdrecht AA, Teule GJJ, Biological effectiveness of 67-gallium decay in HL60 cells compared with external low dose rate gamma irradiation: effects on proliferation, G2 arrest, and clonogenic capacity. Int $J$ Radiat Oncol Biol Phys 1994; 30: 117-124.

26. Van Leeuwen-Stok AE, Drager AM, Schuurhuis GJ, Platier AW, Teule GJJ, Huijgens PC. Gallium 67 in the human lymphoid cell line U-175: uptake, cytotoxicity and intracellular localization. Int J Radiat Biol 1993; 64: 749-759.

27. Goedemans WT, de Jong MTM, Deutz E, Miller KM, Brodack J, Ensing GJ. Development of an In-111 labelled somatostatin analogue: Octreoscan 111. Eur J Nucl Med 1991; 18: 532 . 
28. Behr TM, Sharkey RM, Juweid ME, Aninipot R, Mattes MJ, Stein R, Blumenthal RD, Griffiths GL, Goldenberg DM. Residualizing radiometals (indium, yttrium) versus released (iodine) isotopes in radioimmunodetection and therapy with internalizing antibodies. Eur J Nucl Med 1995; 8: 765P.

29. Roselli M, Schlom J, Gansow OA, Raubitschek A, Mirzadeh S, Brechbiel MW, Colcher D. Comparative biodistributions of yttrium- and indium-labelled monoclonal antibody B72.3 in athymic mice bearing human colon carcinoma xenografts. $J$ Nucl Med 1989; 30: 672-682.

30. Moi MK, Meares CF. The peptide way to macrocyclic bifunctional chelating agents: sysnthesis of 2-(p-nitrobenzyl)1,4,7,10-tetraazacyclododecane- $N, N^{\prime}, N^{\prime \prime}, N^{\prime \prime \prime}$-tetraacetic acid and study of its yttrium(III) complex. J Am Chem Soc 1988; 110: 6266-6267.

31. Stolz B, Smith-Jones PM, Ruser G, Albert R, Briner U, Mäcke H, Weckbecker G, Bruns C. Somatostatin receptor-mediated radiotherapy of cancer, preclinical evaluation of the concept. J Nucl Med 1995; 36: 114p.
32. Hosono M, Hosono MN, Haberberger T, Zamora PO, Guhlke $\mathrm{S}$, Bender H, Knapp FF Jr, Biersack HJ. Imaging of small-cell lung cancer xenografts with I-125, In-111, and Re-188 octreotides. $J$ Nucl Med 1995; 36: 72p.

33. Zamora PO, Guhlke S, Bender H, Diekmann D, Rhodes BA, Biersack HJ, Knapp FF. Experimental radiotherapy of receptor-positive human prostate adenocarcinoma with ${ }^{188} \mathrm{Re}-\mathrm{RC}$ 160 , a directly-radiolabelled somatostatin analogue. Int $J$ Cancer 1996; 65: 214 220.

34. De Jong M, Breeman WAP, Bernanrd BF, Rolleman EJ, Hofland LJ, Visser TJ, Setyono-Han B, Bakker WH, van der Pluijm ME, Krenning EP. [161Tb-DTPA-D-Phe']-octreotide: preparation, in vitro receptor binding and biological activity, metabolism in isolated perfused rat livers and distribution in vivo in normal and tumour-bearing rats in comparison with [111In-DTPA-D-Phe']-octreotide. Eur $J$ Nucl Med 1995; 22: $608-616$. 